Canadian University Music Review

Canadian University Music Review

Revue de musique des universités canadiennes

\title{
Back to the Future: Celebrating Thirty Years of Diversity
}

\section{James Deaville}

Volume 21, numéro 1, 2000

URI : https://id.erudit.org/iderudit/1014473ar

DOI : https://doi.org/10.7202/1014473ar

Aller au sommaire du numéro

Éditeur(s)

Canadian University Music Society / Société de musique des universités canadiennes

ISSN

0710-0353 (imprimé)

2291-2436 (numérique)

Découvrir la revue

Citer ce document

Deaville, J. (2000). Back to the Future: Celebrating Thirty Years of Diversity.

Canadian University Music Review / Revue de musique des universités

canadiennes, 21(1), 1-6. https://doi.org/10.7202/1014473ar
Résumé de l'article

A survey of the history of the CAUSM Journal/Canadian University Music Review from its founding in 1971 reveals how the journal, its contents, and policies have reflected conditions within Canada in general and Canadian musical academe in particular, whereby it has been a scholarly publication that above all has been marked by diversity and border crossing throughout its history.
All Rights Reserved @ Canadian University Music Society / Société de musique des universités canadiennes, 2000
Ce document est protégé par la loi sur le droit d'auteur. L'utilisation des services d'Érudit (y compris la reproduction) est assujettie à sa politique d'utilisation que vous pouvez consulter en ligne.

https://apropos.erudit.org/fr/usagers/politique-dutilisation/ 


\title{
PREFACE-BACK TO THE FUTURE: CELEBRATING THIRTY YEARS OF DIVERSITY
}

\author{
James Deaville, English Editor
}

It is my pleasure to provide a Preface to this special issue of the Canadian University Music Review, from the perspective of English-language journal editor (albeit one who has not been long on the job). ${ }^{1}$ My purposes here are to review the journal as it evolved over the years and to look toward its future in the new millennium. As we shall see, the journal, its contents, and policies have reflected conditions within Canada in general and Canadian musical academe in particular, whereby it has been a scholarly publication that above all has been marked by diversity and border crossing.

The story begins in 1971, when the Canadian Association of University Schools of Music started its own journal under the title CAUSM Journal (1970 was coincidentally the first year of the Learned Societies gatherings). ${ }^{2}$ CAUSM President and Journal co-editor G. Welton Marquis (with Terence Bailey) provided a foreword to the first issue, in which he articulated goals for the journal, goals that should still be familiar to us today:

In addition to serving as an official sounding board for those musicologists, ethnomusicologists, music educators, theorists, composers, performers and others who write something worthy of being placed in print for all of us to see, I see no reason why future issues should not provide all of us with other information. There should be a section for book and recording reviews; we should know about significant performances and publications of new compositions; we should have news of our musical activities-personal and institutional. $^{3}$

Thus, from its very beginnings, the Canadian University Music Review pursued a publication policy of crossing borders. In contrast, disciplinary divisions were asserting themselves in North American musical academe, a trend evidenced by the multiplication of organizations and publications representing individual fields. The Journal would eventually publish reviews, but

11 should note that these reflections are my own, and do not necessarily represent the opinions of the Editorial Board or of the fellow Editors of the Canadian University Music Review.

2See John Beckwith, "CUMS Remembered/Souvenirs de la SMUC," Canadian University Music Review, no. 20/1 (1999): 1-4, for an engaging history of the Canadian University Music Society and its various activities, including the Review.

3G. Welton Marquis, "Foreword," Canadian Association of University Schools of Music Journal 1, no. 1 (1971): 1-2. 
the other items projected by Marquis would either eventually find a home in the Society's newsletter or be realized within other fora. At that time, and also in the intervening years, the only North American society with a similar mandate has been the College Music Society, which began publication of its interdisciplinary College Music Symposium in 1961 (admittedly, that journal has been more consistently successful over the years in attracting contributors from the various sectors of musical academe: musicologists, ethnomusicologists, theorists, educators, performers).

The contents of the first two issues of CAUSM Journal reflect the diversity of the society's contributing membership (the first issue was heavily pedagogical and theoretical, the second primarily musicological):

No. 1 (Spring 1971)

"The Training of Musicians in 2001"

Richard Johnston

"Error in Tonal Harmony: Developing Insight through

Listening"

"The Role of the Electronic Music Studio in University

Music Programs"

"Aims and Methods for a Music-Theory Program"

"Tovey and the Student of Today"

"Towards a Theory of Rhythm"

"A Successful Adaptation of Kodaly's Music Education

Principles"

"Towards a Mozartean Simplicity in Twelve-Note

Tonal Music at the Undergraduate Level"

"Some Suggested Corrections in the Hindemith

Chord Tables"

[anonymous]

Cortland Holtberg

John Beckwith

Peggie Sampson

Carl F. Haenselman

Kenneth J. Bray

Graham George

Dennis M. Farrell

No. 2 (Fall 1971)

"Performance in the Academic Community: Opportunity and Dilemma"

"The Case for Opera at the University"

"The Programme Sonatas of Jan Ladislav Dusík"

"Schubert's Use of Tonality: Some Unique Features"

"Giulio Caccini and the 'Noble Manner of Singing"”

"Toward an Original Format of Mahler's Lieder eines

fahrenden Gesellen"

"Music for Two and Three Lyra-Viols"

"Forerunners of the Keyboard Etude"

Dale Reubart

French Tickner

Gerhard Wuensch

F. R. C. Clarke James Stark

Zoltan Roman

John Sawyer

R. A. Stangeland

In 1980, the CAUSM Journal would be expanded and renamed the Canadian University Music Review. In 2000 it entered its twentieth year of publication under that title. We also celebrate thirty years of continuous publication in the two national languages, which John Beckwith has called "a 
remarkable record." 4 Under its distinguished first editors Alan Gillmor and Jean-Jacques Nattiez, the Canadian University Music Review continued the policy of its predecessor in publishing articles from various areas of Canadian musical academe. Again, this diversity was not just a matter of chance but of policy, as the editors stated in the first number: "We shall continue to publish the best Canadian scholarship in all areas of musical research ... It is our intention to reflect musicological activity in Canada in all its variety."5

A survey of titles and authors from that issue of 1980 again manifests the disciplinary diversity of the publication in its early years. This diversity included historical musicology, ethnomusicology, and music theory, with contributions published by noted scholars from these fields (some of these scholars still being active):

No. 1 (1980)

"Two Unpublished Instrumental Works by Healey Willan"

Frederick R. C. Clarke

"An Assessment of the Organ Miniatures of Healey Willan"

Peter Hardwick

"Polarity in Schubert's Unfinished Symphony"

David P. Schroeder

"Pour l'adéquation de la transcription en ethnomusicologie: l'exemple du katajjaq"

Claudette Berthiaume-Zavada

"La méringue entre l'oralité et l'écriture: histoire d'un genre musical haïtien"

Claude Dauphin

"Le mouvement mélodique et le système tonal de la musique de syamisen"

Yoshihiko Tokumaru

"The Classification of Music: A Survey Study" Robert Falck, Maurice Esses

"Tonal Organization in Schoenberg's Six Little Piano Pieces, Op. 19"

Kenneth L. Hicken

"Reflections on the First Movement of Berg's Lyric Suite"

Leonard Enns

"Record Review" David Piper

The second number, 1981, brought similar pieces by such authors as Marcelle Guertin, Henri Pousseur, Richard Semmens, and-with an article entitled "Towards a Sociology of Musical Styles"-John Shepherd. As the editors note:

the English section of this issue reflects our continuing commitment to the interpretation of musical scholarship in its broadest sense. To this end we are especially pleased to publish two sociological papers which we trust will contribute in a modest way to the removal of the artificial barriers which

4 "CUMS Remembered," 3.

5 Alan Gillmor, Jean-Jacques Nattiez, "Editorial," Canadian University Music Review, no. 1 (1980): vii. 
traditionally have tended to encapsulate the disciplines and keep them uncomfortably apart. ${ }^{6}$

Here we see the editors directly invoking the concept of crossing "barriers" between disciplines, long before it became fashionable or before Joseph Kerman gave his clarion call for musicology to break out of its narrow isolation. Is it possible that this bridging of disciplines is characteristic not only of the Canadian University Music Society throughout it long history, but also of academic life in Canada? Expressed another way, is it possible that the intellectual climate of Canada is conducive to such multidisciplinarity as has characterized the journal?7 Certainly the fruitful interchanges enabled by the annual gatherings of the Learned Societies is a distinguishing feature of scholarship here-in this case, our small size does matter!

It is not a coincidence that what many consider to be the next high point of the Canadian University Music Review occurred at the hands of John Shepherd, who guest-edited the special issue of 1990 (no. 10/2), entitled Alternative Musicologies/Les Musicologies alternatives. This much cited and anthologized issue published proceedings from a 1988 conference of that name at Carleton University. The contributors are well known to us today: besides John Shepherd, they were Susan McClary, Caryl Flinn, Line Grenier, Jean-Jacques Nattiez, Simon Frith, Steven Feld, Peter Wicke, and Will Straw. In my opinion, however, more important for Canadian musical scholarship were the areas represented by the contributions, which included feminism and music, film music, music sociology, musical semiotics, ethnomusicology, and popular music. This was the first time that a Canadian musical journal published on this combination of topics, and arguably the first publication of this grouping of fields in musical research in any format. The issue was ahead of its time: today, musical feminism, film music, and popular music studies are recognized fields of scholarship, but in 1990, they still had to establish themselves in musical academe.

In keeping with the decades of change and accomplishment at the Canadian University Music Review - 1971, 1980, 1990-I need not invoke a millennial prophecy to expect a development as decisive for the journal in the year 2001, which I believe the current issue represents. The difference from the 1990 issue is that here the Review broadens its reach beyond musicological methodology, whichever paradigm. Music education, for example, makes its distinctive mark through the contribution of Wayne Bowman. Thus in many ways, the current issue constitutes a return to the broader "border-crossing" principles that characterized the society and its journal in their early years, only refined into an interdisciplinarity that comes from years of jumping across barriers.

6Alan Gillmor, Jean-Jacques Nattiez, "Editorial," Canadian University Music Review, no. 2 (1981): ix.

7I use the term "multidisciplinary" rather than "interdisciplinary" because the Review has published articles from divergent musical disciplines next to each other, but has yet to feature in its contributions the interpenetration of fields required by interdisciplinarity. The current special issue is a step in that direction. 
I believe it is the quality of crossing borders that will continue to distinguish the Canadian University Music Review from other music periodicals in the scholarly arena. This direction reflects developments in Canadian academic life whereby, for example, positions increasingly require diverse abilities and expertise from candidates. And young applicants themselves embody this post-secondary diversification by acquiring fundamental knowledge in cultural studies, sociology, anthropology, and the like. This applies to music as well, where students are flocking to courses in just those areas that were once borderline: popular music, jazz, film music, non-Western music.

It is my intention to take the Canadian University Music Review into the twenty-first century by continuing to value our distinctive founding policies from thirty years ago. Thus, in shaping our future we are looking to our past, not slavishly imitating it, but allowing the same spirit that formed the Canadian Association of University Schools of Music and gave the mandate to its Journal to guide us. On the one hand, this means attracting contributors from the most diverse musical fields of endeavour, including music education, composition, and performance. The benefits of such a wide net have manifested themselves through the thirty-year activity in the Canadian University Music Review of distinguished Canadian composer John Beckwith, whose thoughtful participation has always provided new insights into how we understand and interpret music and musical life. On the other hand, I believe maintaining our distinctive role in musical scholarship will continue to involve valuing those approaches to music that celebrate our diversity by cutting across disciplines, and that situate our objects of research within broader cultural and social contexts. While not ignoring or demeaning the valuable contributions of individual musical disciplines, this position recognizes that when we write and publish, our work is informed by insights from other fields of inquiry. Thus when we study the isorhythmic motet, we draw upon literary analysis to help understand the relationships between music and words; ${ }^{8}$ or when we conduct a Schenkerian analysis of a song by Schubert, semiotics helps inform our interpretation of the text; ${ }^{9}$ or when we consider Stravinsky's Les noces, we draw upon cultural studies to identify its unique place within evolving primitivism in the early twentieth century. ${ }^{10}$ In this context of interdisciplinarity, I mention the work of long-time contributor John Shepherd, whose sociological viewpoint has insisted upon regarding music as social act rather than fixed text, and thereby has influenced a generation of Canadian music scholars.

The current special issue edited by John Shepherd is a realization of our common vision for the Canadian University Music Review. While each author's contribution reflects the current state of thought in a given musical

\footnotetext{
8 Susan Fast, "God, Desire, and Musical Narrative in the Isorhythmic Motet," Canadian University Music Review, no. 18/1 (1997): 19-37.

9David Beach, "An Analysis of Schubert's 'Der Neugierige': A Tribute to Great Kraus," Canadian University Music Review, no. 19/1 (1998): 69-80.

10Nancy Berman, "From Le sacre to Les noces: Primitivism and the Changing Face of Modernity," Canadian University Music Review, no. 20/1 (1999): 9-21.
} 
discipline, in doing so, each of them also engages in border crossing. I trust that the issue will provoke fruitful and lively discussion.

In closing, I just would like to express the hope that our next decade (or three decades) of publication will continue to be guided by those principles that have given us a distinctive voice within academic publishing in music.

\begin{abstract}
A survey of the history of the CAUSM Journal/Canadian University Music Review from its founding in 1971 reveals how the journal, its contents, and policies have reflected conditions within Canada in general and Canadian musical academe in particular, whereby it has been a scholarly publication that above all has been marked by diversity and border crossing throughout its history.
\end{abstract}

